\title{
The Role of Bureaucracy in Building Rural Development: A Study of Addalaichenai Divisional Secretariat, Sri Lanka
}

\author{
Meerasahibu Abdul Jabbar ${ }^{1, a}$, Thaharadeen Fathima Sajeetha ${ }^{2, b^{*}}$ \\ ${ }^{1}$ Dean, Faculty of Arts and Culture, South Eastern University of Sri Lanka, Oluvil-Sri Lanka. \\ ${ }^{2}$ Assistant Lecturer in Political Science, Department of Political Science, Faculty of Arts and \\ Culture, South Eastern University of Sri Lanka, Oluvil-Sri Lanka.
}

E-mail address: ${ }^{a}$ jabbarma2009@gmail.com , b sajeethaha@gmail.com

Keywords: bureaucracy, rural development, public services, public service delivery

\begin{abstract}
This study examines the role of bureaucracy in building rural development especially Addalaichenai Divisional Secretariat. Rural development is a very important aspect of development progress in a country. Development of the country has to begin from the rural or villages and it depends on the development of its villages. For that every government makes the development policies and gives the authority to the bureaucratic organizations to implement these policies including the grass root level. The main objective of this study to identify the major role of Addalaichenai Divisional Secretariat which is one of the bureaucratic organization to generate the rural development. This study is based on both qualitative and quantitative research methods. Qualitative and quantitative data are gathered by using primary and secondary sources. Primary data is gathered from qualitative interviews, structured questionnaire and limited observation. The secondary data is gathered through published books, research and internet articles. Collected data from different sources as mentioned above is analyzed using qualitative and quantitative methods and it is presented using texts, tables and charts. This research finds out that Addalaichenai Divisional Secretariat obtains the main role in building rural development and identifies the barriers which affect in this progress such as lack of political will and stakeholders support, insufficient resources and capacity, climate change, absence of rural representation and unequal treatment, lack of community involvement and people's perception, lack of awareness and traditional society.
\end{abstract}

\section{INTRODUCTION}

The subject of rural development today is receiving the attention of politicians, administrators, academics and funding agencies more than ever before. It is almost an axiom in the developing countries that the path to national development lies through rural development (Talagune 1984). A country achieves the real development through the success of rural development. Development of a country begins from villages or rural areas and gradually gets up to districts, provinces or federal units and finally ups to the whole country. If a country fails to get the rural development, it will not be as a developed country. The development progress of the country lies on the development of its villages.

The government makes the law and policy on rural development, although its implementation is driven by the bureaucracy. In this scene, bureaucracy occupies an important role in the formulation and implementation of the development plans and programs even in the new economic order in which a reduced governmental intervention in the economic sector. Thus implying a reduced role for the bureaucracy in the process of development is expected. It is responsible for providing variety of services including issuing certificates, providing livelihood facilities, awareness programs and rural development.

Also many governments in developing countries have recently been shifting to decentralization in order to adequately deal with local needs. Due to the necessity for an active local economy within decentralization, rural development is receiving increasing attention.

In Sri Lanka, many plans and projects on rural development are made by the government in different periods. And also the bureaucracy of Sri Lanka has the inevitable role in implementing the 
above. Generally rural development includes various plans and projects such as community development, health, education, agriculture, infrastructure, women and child care, environmental protection and etc.

This paper mainly deals with rural development and the key role of bureaucracy: especially Addalaichenai Divisional Secretariat, Sri Lanka.

\section{RESEARCH PROBLEM}

Bureaucracy works hard to achieve the rural development even though, most of the progress of growth and development that do not full fill the needs and aspirations of rural areas and its people, especially the poor cannot be claimed as development.

1. How does bureaucracy contribute to the rural development?

2. What are the barriers which affect the rural development?

\section{RESEARCH OBJECTIVE}

The objective of this study is to find out the significant role of bureaucracy, especially Addalaichenai Divisional Secretariat in upgrading the rural development and identify the barriers in the process of rural development.

\section{RESEARCH METHODOLOGY}

This study is based on both qualitative and quantitative research methods. Qualitative and quantitative data are gathered by using primary and secondary sources. Primary data is gathered from qualitative interviews, structured questionnaire (50) and limited observation. The secondary data is gathered through published books, research and internet articles. The structured questionnaire which includes qualitative data is analyzed transcribing into quantitative. In this study, collected data from different sources as mentioned above is analyzed using qualitative and quantitative methods and it is presented using texts, tables and charts.

\section{CONCEPTUAL FRAMEWORK}

Rural development is an evolving concept. Many literatures are available related to the rural development, some of them are theoretical and others are empirical.

The word 'rural' is defined in various form in various part of the world. United States Department of Agriculture defines (2002) rural areas as any area other than a city or town that has a population of greater than 50,000 inhabitants and urbanized areas contiguous and adjacent to such a city or town (http://www.geo.mtu.edu). The term rural is usually thought in contrast to urban. This word has not the unique definition and it is used to define based on population density in Japan. However, we cannot simply apply this definition to other countries. Moreover, due to the fact that concept of rural varies from Asia to Africa, it is difficult to define uniformly.

The concept of rural development is used generally to denote the action and initiatives taken to improve the standard of living in non-urban villages. It mostly aims at the socio-economic development of the areas.

Rural development means to the process of improving living conditions, providing minimum needs, increasing productivity, and employment opportunities and developing potential of rural resources through integration of spatial, functional land temporal aspect (Tripathy, 2000).

The World Bank views rural development as "improving living standards of the masses of low income group residing in rural areas, making the process of rural development self-sustaining". As well as Asian Development Institute defines rural development as "delineation of a man vis-avis both the material forces of production and society and a purposeful growth of human personality" (Tripathy, 2000). 
Generally, the term rural essentially means an area, characterized by non-urban style of life. Occupational structure, social organization and settlement pattern or it is essentially agricultural, homestead settlements, independent social life and slow moving rhythm of life built around nature. The aim of rural development can be defined as the improvement of sustainable livelihoods with careful attention paid to local characteristics.

\section{RESEARCH AREA}

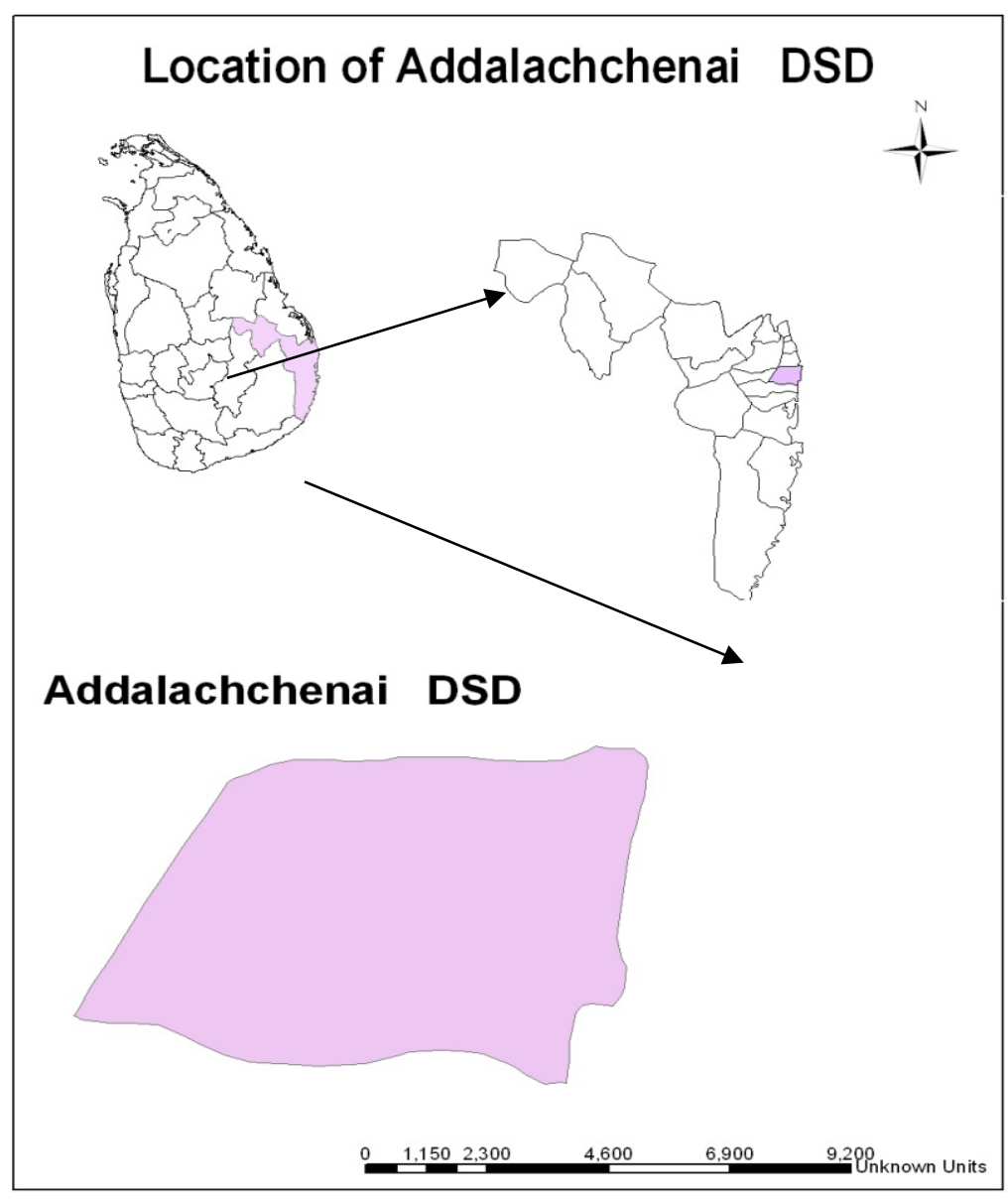

Figure 1

Source: Arc Gis vesiorn 0.9

Addalaichenai Divisional Secretariat has been chosen to the case study. It is one of the bureaucratic organization situated in Ampara district of Eastern Sri Lanka. It has four villages as follows; Addalaichenai, Palamunai, Oluvil, Deegavapi and 32 G.S. division. Its population is 45,120 (Resource Profile, Addalaichenai Divisional Secretariat 2013). There are three major ethnic and religious groups living together. They are Muslims, Tamils, and Sinhalese. Addalaichenai Divisional Secretariat delivers the services equally, although, people of this area are not satisfied on this service delivery and development process. And there are many challenges faced by people and administrators on this regard. The below table (Table 1) shows the population of the research area in ethnic vise. 
Table 1

\begin{tabular}{|c|c|c|c|c|}
\hline \multicolumn{5}{|c|}{ Population by Ethnic Group in GN Division - 2013 } \\
\hline \multicolumn{1}{|c|}{ Sex } & Sinhalese & Tamils & Muslims & Total \\
\hline Male & 1,094 & 210 & 20,809 & 22,113 \\
\hline Female & 1,032 & 202 & 21,773 & 23,007 \\
\hline Total & $\mathbf{2 , 1 2 6}$ & $\mathbf{4 1 2}$ & $\mathbf{4 2 , 5 8 2}$ & $\mathbf{4 5 , 1 2 0}$ \\
\hline
\end{tabular}

(Resource Profile, Addalaichenai Divisional Secretariat 2013).

\section{FINDINGS AND DISCUSSION}

According to the data analyzing, several types of organizations contribute to the rural development in the research area although, bureaucratic organizations occupy the leading places. The below bar chart 1 shows that clearly.

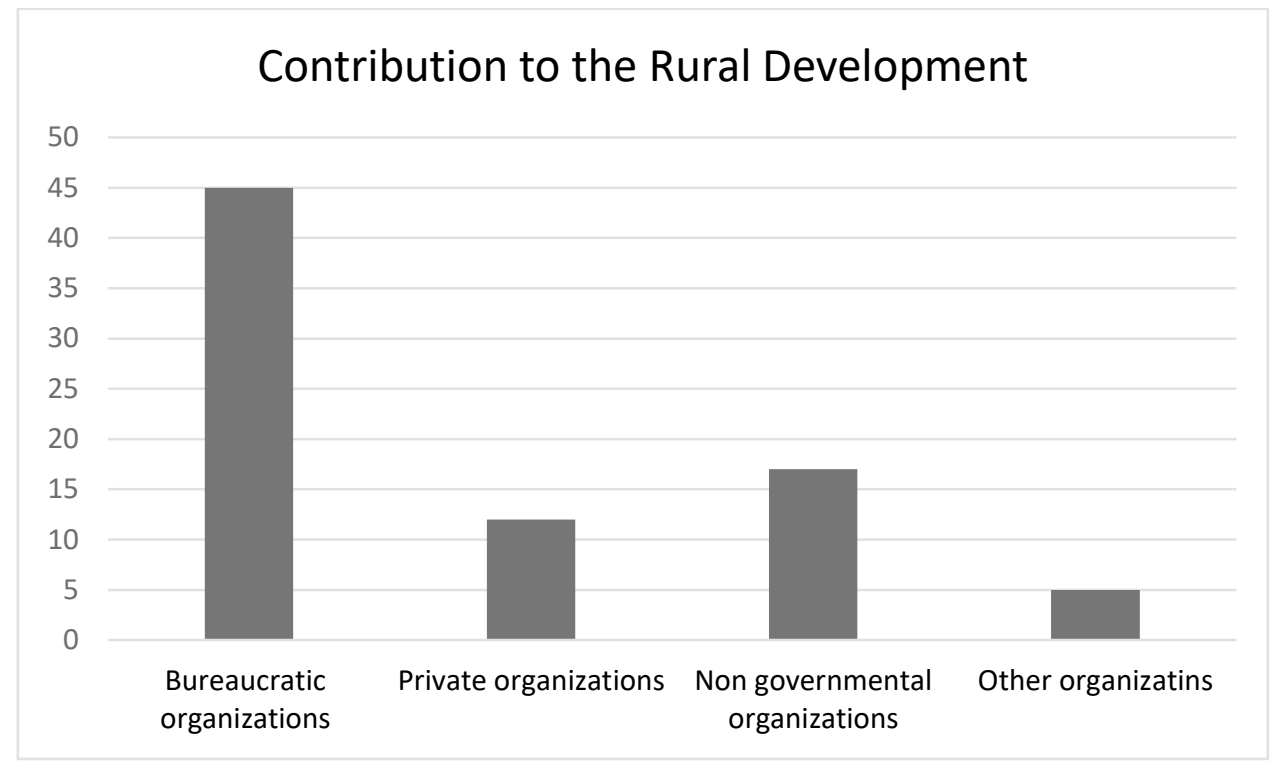

Chart 1

This study explores that Addalaichenai Divisional Secretariat is one of the bureaucratic organizations in Sri Lanka and important public institution to deliver the public services which are essential to the people in this area. It has many divisions such as land, administrative, social care centre, accounts, cultural, planning divisions and etc. to provide the different types of services. Even though, all divisions of Addalaichenai Divisional Secretariat deliver the lots of services including rural development through the various ways. For that it has most essential bureaucratic posts related to the different parts of the rural development and each unit of the divisional secretariat contributes to the above process under the different ministries.

Following are the functions of each division of Addalaichenai Divisional Secretariat. 
Table 2

\begin{tabular}{|l|l|}
\hline \multicolumn{1}{|c|}{ Division } & \multicolumn{1}{c|}{ Functions } \\
\hline Administration & $\begin{array}{l}\text { Issuing License } \\
\text { Certificates } \\
\text { Renewing License } \\
\text { Collecting Revenue }\end{array}$ \\
\hline \multirow{3}{*}{ Social Care Centre } & $\begin{array}{l}\text { Relief } \\
\text { Elders Identity } \\
\text { Food Stamp } \\
\text { Housing }\end{array}$ \\
\hline Accounts & Payment \\
\hline Planning & $\begin{array}{l}\text { Development works } \\
\text { Identify the development process and local -resources }\end{array}$ \\
\hline Registrar & Accepting and issuing he birth, wedding and death certificates \\
\hline Pension & $\begin{array}{l}\text { Pension for retired government officers or their families and } \\
\text { the widows }\end{array}$ \\
\hline
\end{tabular}

Divisional Secretariat takes the direct administration and very close relationship with the people. It not only provides the public services to the citizens but also monitors and measures this process. It brings the rural development under the different projects such as Divineguama, Gamaneguma, Maganeguma. These projects are round in building up the home economic. Through the improvement of home economics the development can be reached in each level from home to country.

Bureaucrats such as Rural Development Officer, Women Development Officer, Cultural Officer, Skill Development Officer, Child Care Officer, Early Childhood Development Officer, Counselling Officer, Child Rights Promoting Officer, Housing Officer, Sports Officer, Agricultural Officer, Industrial Officer and Fishing Officer work in different development process of this area. All their works contribute to achieve the rural development.

To achieve the rural development, the bureaucrats of the divisional secretariat implement various plans. They are following: health, education, environmental protection, women development, occupational training, rural agriculture, vet nary, self-employment, cottage industry, microcredit, entertainment programs, sports, ethics, and projects for special needs people.

Further above, Rural Development Officer is a recruited person specially to deal these process. Under this post, many development works are generated by the people who are organizing as societies for different purposes. They act according to the guidelines of the rural development officer. Most of the development works are initiated by these societies themselves and bureaucrats run and control these development works.

To gain these development, lots of activities are brought by the administrators. Many awareness programs are conducted on pregnant ladies, environmental cleaning, empowering women, self-earning. As well as pre-school forming, education for the poor, motivate the reading habit, donate or sponsor for some books or magazine to the public library and giving exercise to write for the elders are the activities to promote the education level in this area.

As well as to protect the environment, shiramathana and dengue eradication are implemented with the help of people. And also to improve the livelihoods, provide the microcredit, vocational training, give some professional equipment such as bicycle, machineries, fishing net to the rural people. Divisional Secretariat takes the role in maintain the cottage industry. It provides some materials and gives the guidelines to use the local resources and identify the market opportunities. Under the Rural Development Officer, every year it provides the one year professional diploma for 30 people. Some of them get the admission to the Government College of Education due to this certificate. 
As well as many awareness programs and counseling programs are conducted by the Women Development Officer and Counseling Officer for the rural women on domestic violence, family problems and also self-employment opportunities. It tries to make the women independently.

Addaliaichenai Divisional Secretariat makes the arrangements to improve the vulnerable people. It provides the wheel chair, medical treatment, self-employment needs to these people and back to their normal. As well as, through the Divineguma many helps are given to improve the home economic. Payment for elders, housing plans, relief, Samurthi are the programs for the development of the vulnerable people. Divisional Secretariat initiates many programs to the infrastructure development such as road development, remove the drainage water with the help of rural people who are organized as a society.

Also housing is one of the basic needs of human being. In this area, most of the houses are in good condition although the poor do not have enough financial resources to improve their housing needs. Some of them started build a new houses with the help of bank loans and others. In this time, Social Care Centre and Samurthi of Addalaichenai Divisional Secretariat provide the housing plans and facilities to the specific number of vulnerable people per every year. Gamaneguma and Maganeguma projects are also formulated to improve the rural infrastructure development.

Following table 3 and pie chart 2 explain the contribution of Divineguma in rural livelihood development.

Table 3

\begin{tabular}{|l|l|c|c|}
\hline \multicolumn{4}{|c|}{ Divineguma Livelihood Development Project 2014 } \\
\hline No & Name of Project & No. of Beneficiaries & Expenditure \\
\hline 01 & Agriculture & 09 & 439,650 \\
\hline 02 & Livestock & 154 & $1,534,500$ \\
\hline 03 & Fishery & 12 & 469,500 \\
\hline 04 & Industry & 63 & $1,661,350$ \\
\hline 05 & Marketing & 14 & 273,000 \\
\hline \multicolumn{2}{|c|}{ Total } & $\mathbf{2 5 2}$ & $\mathbf{4 , 3 7 8 , 0 0 0}$ \\
\hline
\end{tabular}

(Resource Profile, Addalaichenai Divisional Secretariat, 2014).

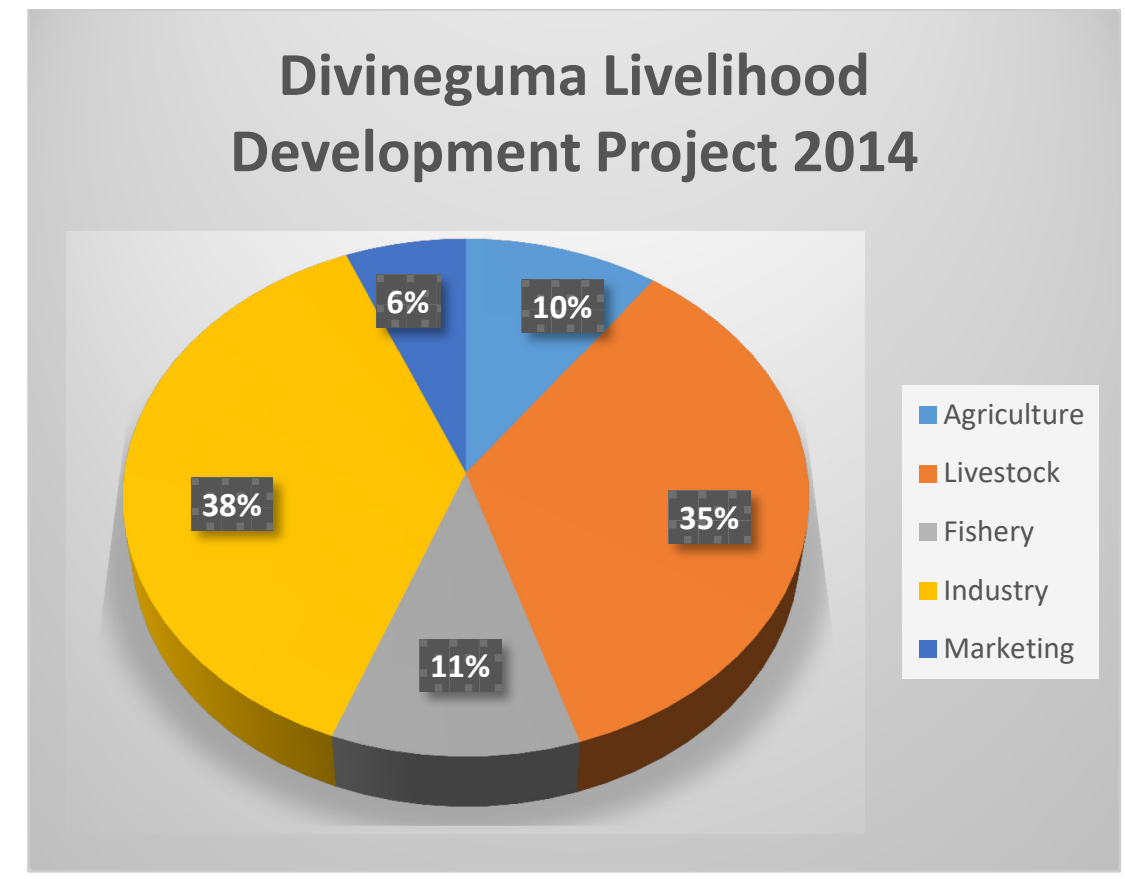

Chart 2 
The Samurdhi program was introduced in 1995 as a poverty alleviation program in Sri Lanka and replaced Janasaviya beneficiaries to the program, when considering Samurdhi program, it consists of a short term component to protect the poor by reducing their vulnerability and a long-term program to assist them to graduate out of poverty. The program comprises with three main strategies to eradicate poverty. They are: (1) A welfare component (2) Saving and credit program (3) Self-help work program.

The below table 4 explains the number of Samurthi beneficiaries and total expenditure.

Table 4

\begin{tabular}{|c|c|c|c|c|}
\hline & Addalaichenai & Palamunai & Oluvil & Deegavapi \\
\hline No. of Benificeries & 2,952 & 1,056 & 1,050 & 245 \\
\hline Expenditure & $1,809,900$ & 646,320 & 645,150 & 150,810 \\
\hline
\end{tabular}

(Resource Profile, Addalaichenai Divisional Secretariat, 2014).

All these developments have four types of objectives on rural development. They are; improvement of economic capabilities (livelihood), improvement of human capabilities (health and education), improvement of protective capabilities (natural environment, disaster and violence) and improvement of political capabilities (participation and decision making).

From the above, we can understand that Divisional Secretariat takes the main role in building up the rural development. It generates these development process with the co-ordination of rural people. Its activities related to the rural development, empower the rural people in socio-economic vise and help to promote the capacity building of them. Anyhow it faces many challenges in this regard.

\section{BARRIERS AND CHALLENGES TO THE RURAL DEVELOPMENT}

Addalaichenai Divisional Secretariat helps the rural people to get the services quickly and easily to fulfill their needs and develop them. But practically, bureaucrats and rural people face many potential barriers and challenges to the rural development.

1. Lack of political will and stakeholder's support

At the highest level, political support for rural development is crucial for setting strategies direction, planning resources and enforcing implementation. When bureaucrats are doing their duties according to the rules and circulars they give the priorities for some, but politicians intervene into this process and insist to act favor for them. Sometime rural development projects often change due to the changes of government and government's policies. That's why, a project which is exercised currently has the prospects to change or stop before its success. The government allocation to the rural development is not enough. As well as Divisional Secretariat suffers to get the people and stakeholder's support. When it comes to implement a new project, people do not give the support as the lack of awareness. Sometime rural people compelled to include them in a development project which is limited for the specific number of people. And also they do not understand the future objective of project and they concern only the present.

2. Insufficient resources and capacity

Sri Lanka is a developing country which has to initiates the development process with rare resources. In the research area, Addalaichenai Divisional Secretariat has got a limited resources including finance. It does not get the enough allocation from the government and does not get it on time. That's why other material resources cannot be obtained in on time. As the above Divisional Secretariat faces the trouble to distribute the resources to the people equally. 
3. Climate change

Climate change affects the rural poor more, because they reside in geographically and environmentally with poor infrastructure such as roads. And also floods and droughts affect more drastically their livelihoods, including crop production. As well as it disturbs the rural development process of Addalaichenai Divisional Secretariat such some activities are delay due to these climate changes.

4. Absence of rural representation and unequal treatment

As Addalaichenai Divisional Secretariat is being an administrative body not a political organ, people representatives who speak on behalf of the people at the government level, will not be there. It is a bureaucratic organization and get the permanent staff people cannot claim the equal development. Sometime bureaucrats are unfair to deliver the services. They almost concern the people who are relatives and friends. Some administrators are not flexible to the citizens and they follow the rules and regulations harshly. It makes the people to the negative mind on the bureaucracy and bureaucrats.

5. Lack of community involvement and people's perception

Rural development is not only brought by administrators but also the rural people. If a development process gets the community involvement it will be success. In the research area, all people are not interested to involve in this process voluntarily. As development projects almost concern the improvement of vulnerable people, others feel that it is not for them. Sometimes people feel themselves that they are neglected. That's why they avoid to go to the administration and developing progress. As well as some people scold and attack the bureaucrats.

6. Lack of awareness and traditional society

Divisional Secretariats usually conduct the awareness program to promote and empower the women and vulnerable. As far as the research area is concerned, it has mostly traditional society. When bureaucrats invite the people to join these development works and awareness programs, other's perception is different and they criticize the bureaucrats. They feel that bureaucrats do not empower the people and they misguide the people to damage their traditional society. Counseling programs often face this challenge.

The above factors contribute to affect the role of Addalaichenai Divisional Secretariat in building rural development to without full satisfaction. People's satisfaction of the role of Addalaichenai Divisional Secretariat in rural development is found from the data analyzing.

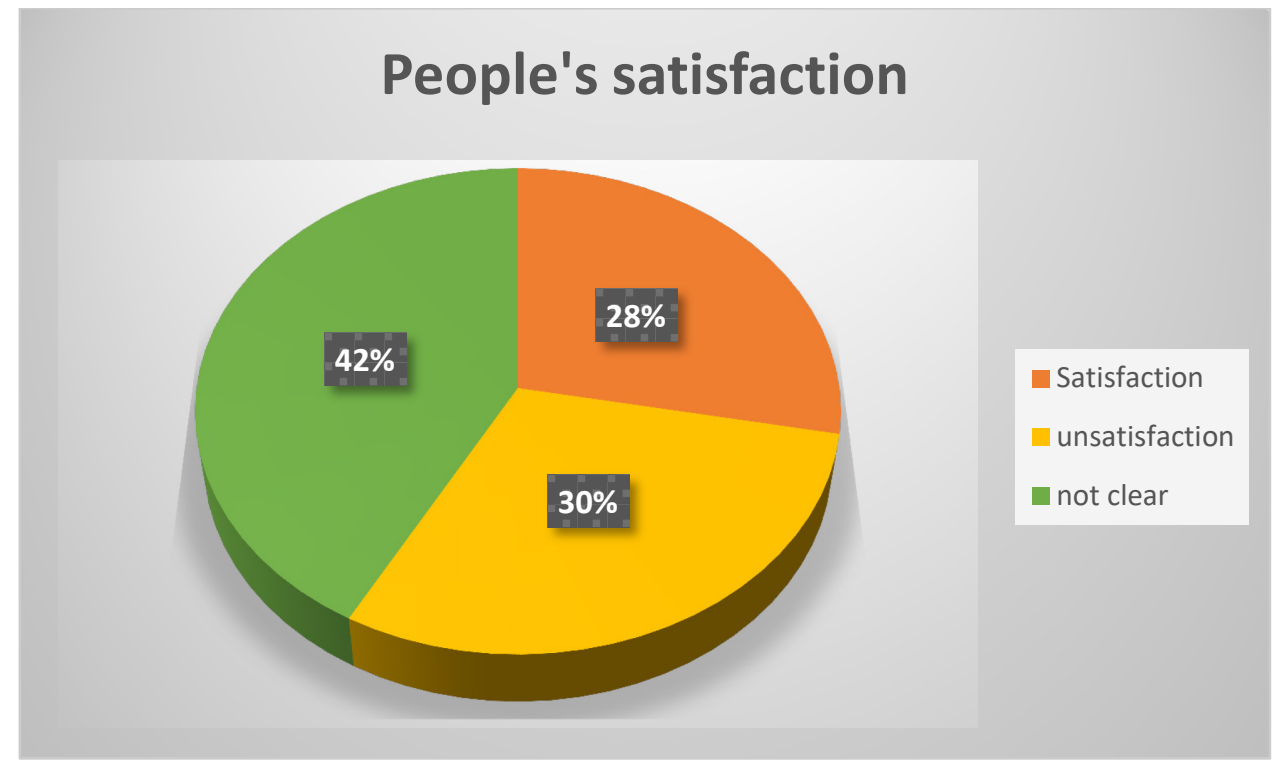

Chart 3 


\section{CONCLUSION AND RECOMMENDATION}

This study explains the role of bureaucracy in building rural development especially Addalaichaenai Divisional Secretariat, Sri Lanka. Rural development is the initial stage of the development process in a country. It includes not only the infrastructure, but also empower the rural people in socioeconomic and cultural vise. This study is based on qualitative and quantitative research method. It tries to find out the role of bureaucracy and barriers which affect the rural development.

According to the study Addalaichenai Divisional Secretariat contribute to the rural development in many ways through the bureaucrats, especially Rural Development Officer (RDO) with the cooperation of rural people. But there are number of causes have affected on the development of this area. To overcome these challenges it is important to take the more concentration about the redesigning mechanism of rural development. So that, the recommendations are proposed below to overcome the above barriers and generate the rural development effectively.

- Introduce a new system to effective participation of rural people and other stakeholders in bureaucracy to ensure the rural development

- Increase the number of vocational training for the younger generation

- Make guidance to start self-employment

- Initiates the disaster management process in the lower level

- Generates the awareness program to the people about the development process by using various medias

- people's representatives should take more concentration about the effective development works

- Emphasize and maintain to follow the aspects and mechanism of good governance in the bureaucratic organization

Finally, rural development is one of the most important things for the country's development process. As a result of this study, many barriers and challenges are found out in building rural development, it has become difficult to provide the required services to the citizens in efficiency and effective manner. Divisional Secretariat runs the rural development works, although, it has no sufficient public support in this regard. Even, emerging the contemporary developments also does not make the changes in this mechanism. Therefore, the Divisional Secretariat has to take the necessary actions to redesign the system of rural development with the co-ordination of people and bureaucrats who are related to particular development works. It would make the opportunities to reduce and resolve the above challenges and increase the successful development of rural.

\section{References}

[1] Anita Kelles-Viitanen. (2005). New Challenges and Opportunities for Rural Development. IFAD Workshop in Rome. [Online]. (http://www.ifad.org/innovation/presentations/newopp.pdf).

[2] Arndd V. Burlingham, Wesley N. Townsand. (eds). (2008). Rural Development Issues. Nova Science Publishers Inc.

[3] Definitions, Terms and Concepts: Rural and Rural Development. [Online]. (http://www.geo.mtu.edu/ asmayer/rural_sustain/intro/Module1c.pdf).

[4] Effective Approaches for Rural Development - Chapter 4. [Online]. (http://jicari.jica.go.jp/IFIC_and_JBICI-

Studies/english/publications/reports/study/topical/spd/pdf/chapter4.pdf).

[5] Jitendra Kumar Sharma. (2001). Rural Development in South Asia. New Delhi: Authors Press.

[6] Jorge Tarchitzky . Rural Development. Israel: Ministry of Agriculture and Rural Development. [Online]. (http://www.un.org/esa/agenda21/natlinfo/countr/israel/ruraldevelopment.pdf). 
[7] Mathur, B.C. (2004). Good Governance and Bureaucracy. New Delhi: Radha Publication.

[8] Resource Profile. (2013) \& (2014). Addalaichenai Divisional Secretariat.

[9] Simon Maxwell, Ian Urey and Carolyne Ashley. (2001). Emerging Issues in Rural Development. London: Overseas Development Institute. [Online]. (http://www.odi.org/sites/odi.org.uk/files/odi-assets/publications-opinion-files/5898.pdf).

[10] Singh, Katar. (1999). Rural Development Principles, Policies and Management. (2 ${ }^{\text {nd }}$ edn). New Delhi: SAGE Publications Pvt. Ltd.

[11] Steven Dukeshire \& Jennifer Thurlow. (2002). Challenges and Barriers to Community Participation in Policy Development. Rural Community Impacting Policy. [Online]. (http://www.ruralnovascotia.ca/documents/policy/challenges\%20and\%20barriers.pdf).

[12] Sujeewa Prathapage. (2006). The Impacts of Rural Poverty on Human Development in Sri Lanka: A Case Study From a Village in Kandy District. M.Phill Thesis. Norwegian University of Science and Technology. [Online]. (http://www.divaportal.org/smash/get/diva2:126245/FULLTEXT01.pdf).

[13] Talagune, A.B. (1984). National Perspective on Rural Development. Journal of Social Sciences. Vol 7, No 1 \& 2, Sri Lanka.

[14] Tripathy, S.N. (ed). (2000). Rural Development. New Delhi: Discovery Publishing House.

[15]U.S. Department of Agriculture. Rural development: report on the definition of "rural". United States Department of Agriculture. [Online].

(http://agriculture.house.gov/sites/republicans.agriculture.house.gov/files/pdf/reports/USDARu ralDefinitionReport.pdf).

[16] Verma, B.R. (1998). Bureaucracy and Administration. New Delhi: Kandhka. 